\section{Journal of Global \\ Management Sciences}

Vol. 2, $\mathbf{N}^{\circ}$ 2, 2019

\title{
The Public administration from Peru in covid-19 time: An analysis \\ [La Administración pública del Perú en tiempos del coronavirus 2019: Un análisis]
}

Sonia Valverde Flores

Universidad Privada de Trujillo, Lima-Peru

Smvf65@hotmail.com

Received: 14 Febrary 2020; Accepted: 19 June 2020; Published: 13 August 2020

\section{Resumen}

Este análisis pretende dar una explicación acerca de las decisiones de la administración pública del Peru en tiempos de la pandemia hasta ahora. En este escenario, es inevitable cuestionarse si la Administración Pública, al imponer medidas estrictas contra los ciudadanos, logra disminuir el nivel de contagio de las personas, asicomo incrementar la recuperación de la salud de las personas y evitar que continúe el contagio masivo.

Palabras clave: Administración pública, covid-19, salud, contagio, análisis.

\begin{abstract}
This analysis intend to explain about to decisions of public management from Peru in covid-19 pandemia times until now. In this scenario, it is inevitable to question whether the Public Administration, by imposing strict measures against citizens, manages to reduce the level of contagion of people, as well as increase the recovery of people's health and prevent the massive contagion from continuing.
\end{abstract}

Keywords: Entrepreneurship, Business Incubator, Canvas Model, Incubation Model, Spin Off. 